\section{Meteor Showers}

The two principal showers of this week are the Taurids II., radiant R.A. $80^{\circ}$, Decl. $23^{\circ}$ N., near $\zeta$ Tauri ; and the Geminids, radiant near a Geminorum; the former should be specially looked for on December 6, the latter December 9-12. Fireballs have frequently been seen during the latter period. Another shower from Taurus, R.A. $56^{\circ}$, Decl. $6^{\circ} \mathrm{N}$., near $\nu$ Tauri ; and another from Gemini, R.A. $108^{\circ}$, Decl. $20^{\circ}$ N., near $\zeta$ Geminorum, have also been sometimes observed during this week.

\section{Objects with Remarkable Spectra}

257 Schj. -R.A. 2Ih. 5om. 58 s., Decl. $49^{\circ} 57^{\prime} \cdot 2$ N. Mag. 9' Secchi's fourth type. The dark band in the yellow is abnormally broad.

r9 Piscium.-R.A. 23h. 4 om. 3 Is., Decl. $2^{\circ}{ }_{5} \mathrm{I}^{\prime} \circ \mathrm{O}$ N. Mag. $6 \cdot 2$ One of the finest examples of the fourth type of spectrum.

Mr. Marth has called attention to the following conjunction of Saturn with DM. $22^{\circ}{ }_{3} 88_{3}$, which should be watched, as it may possibly prove to be an occultation :-

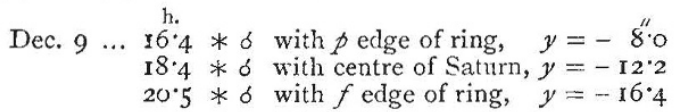

The magnitude of the star is 8.7 .

\section{GEOGRAPHICAL NOTES}

THE Invalide Russe publishes the following telegram from Col. Prjevalsky from Pishpek, but dated Karakol, 2nd (N.S. 14th) November:- "Our voyage has ended happily, and with the most encouraging scientific results."

Ar the meeting of the Paris Geographical Society on the 2oth ult., M. Alphonse Milne Edwards in the chair, the return of M. de Brazza was announced, as well as his promise to read a paper before the Society on his journeys in the Congo. The President also reported the return of $M$. Aubry from more than two years' exploration in Choa and part of the country of the Gallas, Danakils, and Somalis. During that time he determined the course of the Haouach River and its affluents, the Mongueur, Goudredet, and Ganjad, as well as the heights of various mountains. He was also able to make numerous observations on the geology, palæontology, and mineralogy of the region. M. Duveyrier stated that the altitude of $\mathrm{Fez}$, which has never before been determined, is about to be calculated by M. Feraud, by the barometer, to within 10 metres. He has found it necessary to make no fewer than 127 observations in order to obtain this result. M. Coudreau referred to the latest stage of the dispute between France and Brazil with regard to the territory lying between French Guiana and Para.

THE Bulletin (1885, No. 5) of the Belgian Society of Geography contains a long paper by M. Leclercq on Mexico, which is really a translation and résumé of a recent Mexican publication. The present paper is arranged under the following heads :- Situation and boundaries, institutions, political divisions and population, ethnography, with an approximate census of the Indian tribes, industries, railways, and other methods of communication, orography, climate, and productions. It is thus, it will be perceived, a tolerably complete account of the Mexican States.

THE Boletin of the Geographical Society of Madrid for October (vol. xix. No. 4), is, as might be expected, mainly occupied with the Caroline Island question. The only map attached to the number is one of the Western Pacific from the Philippines on the west and New Guinea on the south, including the Pelew, Caroline, Marshall, Gilbert, and Ladrone or Marianne groups. The first contribution is a letter from the Society by its authorised officers to the Government on the question, and claiming the islands as belonging historically to Spain.

IT is stated that an accurate survey of the Island of Yezo, and the neighbouring islands (especially the Kuriles), is to be made by the Japanese Naval Department. It is anticipated that the work will occupy four years.

An Exhibition of Appliances used in Geographical Education in England and on the Continent will be opened by the Royal Geographical Society at 53, Great Marlborough Street, on December 9 , and will remain open till January $3 i$.
THE latest numbers of the Verhandlungen of the Berlin Geographical Society (Band xii. Nos. 7 and 8) contain papers by Dr. Penck, on the mountain systems of Central Germany ; and by Dr. Schulz, on a journey from Port Natal to the Kalahari, and especially the exploration of the Rivers Chobe and Cubango. Dr. Rath (in No. 8) contributes a geographico-geological study of the Pacific regions of North America, and the substance of a lecture by Dr. Buchner on the Cameroons is also given.

A CORRESPONDENT with General Scratchley in New Guinea reports that $\mathrm{Mr} . \mathrm{H}$. O. Forbes is going to attempt to reach the summit of Mount Owen Stanley, 13,205 feet high, and hitherto untrodden by the foot of man. Mr. Forbes will form a depôt camp at Sogeri, 25 miles inland, and survey, collect specimens, \&c., in the neighbourhood of the lower ranges. Next spring, when the weather will be suitable, he will make the attempt to climb to the highest point. He may, the correspondent says, spend several years in New Guinea, for his wife is following him, and his heart is thorouglily in his work.

THE Swedish Society of Anthropology and Geography has commissioned Baron Schwerin, Professor of Geography at the University of Lund, to proceed on a scientific expedition to the Congo, the chief objects being to make geographical, meteorological, botanical, and zoological studies in the new State, and to collect ethnographical objects. Barons Nordenskjöld and Dickson have lent the Expedition a number of valuable instruments. The Swedish Government have requested Prof. Schwerin to report on the commercial opportunities afforded on the Congo and the position of Scandinavian subjects there.

\section{EXPLOSIONS IN COAL MINES ${ }^{1}$}

THE address to which the members of the Society of Arts were so good as to afford a favourable reception at the opening meeting of last Session, was in great measure devoted to topics suggested by the International Health Exhibition of that year. Wide as was the scope of that Exhibition, which dealt not only with the necessaries and comforts of life, and the promotion of bodily health in the feeding, clothing, and housing of all classes, but also with the all-important subjects of physical and mental training, the Exhibition of Inventions-which has just terminated a prosperous and, I believe, a very useful career - embraced a wealth of material for study which could bear comparison, as regards extent and interest, with that presented by any one of the great International Exhibitions of former years, the initiation of which we owe to that illustrious Prince whose memory the Society of Arts delights to honour.

I have resisted the temptation to devote this evening to a brief review of some of the chief matters of interest presented by the most prominent sections of the Exhibition, because I entertain a lively hope that a thorough examination of at any rate many. of these will afford topics for important communications to this Society, and I consequently feel that it would be scarcely just to those who may consent to devote themselves to their preparation, were I to cull specially attractive matter from the mass of information opened up to the student by the achievements demonstrated at the Exhibition. I therefore propose to limit myself in this address to the treatment of some matters relating to only one branch of a division of the Exhibition, namely, the class which deals with machinery and appliances used in mines.

I venture to think that this class of subjects has claims to special interest, because the mining industry ranks amon' the most important sources of the wealth and cosmopolitan influence of the Empire ; because its development and successful pursuit have involved the utilisation of the resources of many branches of applied science, and have taxed the talents and ingenuity of some of our greatest mechanics, and most accomplished physicists and chemists; and, though last, not least, because the pursuit entails the encountering of dangers and vicissitudes which will aptly bear comparison with those involved in the careers of the soldier and the sailor. Thrilling and harrowing accounts of great disasters in coal mines direct public attention from time to time to certain special dangers which the miner has to encounter, but the annual reports of H.M. Inspectors of Mines show that there are yet others to which miners in general are daily exposed, which, although they do not attract public attention (partly because of the very circumstance of their constant occurrence, and partly because the sufferers by them meet their deaths in most cases

I Address of Sir Frederick Abel, Chairnan of Council of the Society of Arts, delivered at the opening meeting, Nov. 18,1885 . - (Abstract by the Author.) 